\title{
Perceptions About the Labor Market Integration of Refugees: Evidences from Syrian Refugees in Jordan
}

\author{
Zeynep Sahin Mencutek ${ }^{1,2}$ (D) Ayat J. Nashwan ${ }^{3}$
}

Published online: 19 March 2020

(C) The Author(s) 2020

\begin{abstract}
This article focuses on the refugees' labor market integration in the immediate host countries. Drawing from the experience of Syrian refugees in Jordan, it describes how the integration in labor market depends on the alignment of four perspectives: (1) host state perspective, materialized through legal regulations about refugee employment; (2) refugee perspective that refers to refugees' access to labor market and challenges they face; (3) host community perspective that implies to the recognition, approval, or reactions of host communities to the refugee employment; and (4) donor perspective that appears with the intervention of international actors through development aid or general support to refugees' working rights. To explore these diverging perspectives and their implications about the labor market integration of Syrian refugees in Jordan, the data is gathered from ethnographic policy analysis and stakeholder interviews in urban areas and camps. We argue that the refugees' legal right to work is one of the most contentious policy issues not only for Jordanian state but also for its relations with Jordanian citizens, refugees, and donors. From the perspective of donors, ensuring Syrians' legal access to labor market in the immediate host countries, like Jordan, is a policy tool for keeping refugees in the origin region. At the host community level, the issue appears as a source of dilemma; because refugee employment is a critical domain for refugees' self-reliance and local integration on the one hand, it is perceived as the source of competition for already scarce job opportunities on the other hand. For refugees themselves, an access to labor market and getting support are ways of gaining sustainable livelihood opportunities, self-reliance, and dignity. However, this access is marked by severe conditions of exploitation, vulnerability, and discrimination in working places as well as the anti-refugee rhetoric of local host communities. Programming in refugee employment necessitates taking all these four perspectives into account.
\end{abstract}

Keywords Refugee policies · Labor market integration · Syrian refugees · Jordan · Refugee employment · Compact

Zeynep Sahin Mencutek

zeynepsahinmencutek@gmail.com

Ayat J. Nashwan

ayat.n@yu.edu.jo

Extended author information available on the last page of the article 


\section{Introduction}

Refugees' labor market integration is a key challenge for many host states; it is also considered significant factor easing long-term integration of refugees into society and possible contribution of them to the host state (European Parliament 2016). The existing studies on refugees' labor market integration mainly focus on the experiences of refugees settled in European countries, the USA, Canada, and Australia (Potocky 1997; Waxman 2001; Colic-Peisker and Tilbury, 2007; Bloch, 2008; Beaman 2011; Bevelander \& Pendakur 2014). However, the studies addressing the issue in the top refugee hosting countries in the Global South such as Turkey, Pakistan, and Tanzania where host more than half of refugees are limited (Schultz, 1994; Turner, 2015; Tumen, 2016; Ali et al. 2018; UNHCR 2018). ${ }^{1}$ This study aims at providing insights to understand the perspectives about the labor market integration of refugees in one of the main refugee hosting countries of Global South, in this way to contribute the existing theories about integration.

The study defines the labor market integration as the access of refugees to labor market -private sector, public sector, and self-employment - without facing legal impediments, exclusion, discrimination, and exploitation due to their refugee status. Drawing from the experience of Syrian refugees in Jordan, it describes how the integration in labor market depends on the alignment of four perspectives: (1) host state perspective, materialized through legal regulations about refugee employment; (2) refugee perspective that refers to refugees' access to labor market and challenges they face; (3) host community perspective that implies to the recognition, approval, or reactions of host communities to the refugee employment; and (4) donor perspective that appears with the intervention of international actors through development aid or general support to refugees' working rights. Taking all these four perspectives may contribute programming in refugee employment by complying with international labor standards.

Jordan is selected as an exemplary case study because it is historically one of the main refugee host countries for Palestinian, Iraqi, and Syrian refugees. Currently, it hosts the second largest number of refugees relative to the size of its population and the third main host country for Syrian refugees. The issue of refugees' legal right to work has been one of the most contentious policy issues not only for Jordanian state but also for its relations with Jordanian citizens, refugees, and donors as it intersects with the country's demographic dynamics, economy development vision, and relations with external actor. From the perspective of international donors, ensuring Syrian refugees' legal access to labor market in the immediate host countries, like Jordan, is the most effective way for keeping refugees in the origin region. For Jordanian citizens, refugees' access to labor market is a source of dilemma, because it is necessary for refugees' self-reliance and local integration, but it is also perceived as a source of competition for already scarce job opportunities. For Syrians, an access to labor market is a way of gaining sustainable livelihood opportunities, self-reliance, and dignity. However, their refugee status put them into severe conditions of exploitation,

\footnotetext{
${ }^{1}$ A leading magazine in the Forced Migration Studies, the Forced Migration Review, has recently published a specific issue (Issue 58, June 2018) covering 22 short articles addressing employment of refugees mainly in the main refugee hosting countries. Source: https:/www.fmreview.org/sites/fmr/files/FMRdownloads/en/economies. pdf.
} 
vulnerability, and discrimination in working places as well as facing directly with the negative opinions of local Jordanians.

Methodologically, the study adopts the qualitative methodology, particularly ethnographic policy analysis, interviews, and desk research. The data about policies was gathered from speeches of Jordanian policy makers, policy papers, documentary sources of the ministries and European Union (EU), open public sources, reports of intergovernmental (IGOs) and nogovernmental organizations (NGOs), scholarly work, and ethnography. The data on the implementation of policies on the local level and refugees' experiences about working were collected via fifteen semi-structured in-depth interviews with Jordanian policy implementers who deal with refugee employment as well as Syrians who have an employment experience in Jordan. We created a purposive sample among stakeholders from Irbid, Amman, Zarqa, and Mafraq. These four provinces are the most populous provinces of Jordan and host large number of refugees. Of the 666,596 UNHCR-registered refugees in the country [as at July 312,018], 89.3\% live in these four provinces: 29.3\% are in Amman, 24.4\% in Mafraq, $21 \%$ in Irbid, and $14.6 \%$ in Zarqa (UNHCR Operational Data Portal2 n.d.). Irbid, Zarqa, and Amman are sites of urban settlement of refugees, while camp refugees were interviewed in Mafraq where Jordan's largest camp, Zaatari, is located. To triangulate the data more, authors conducted expert interviews with both researchers studying migration in Jordan and representatives of international nongovernmental organizations who have been able to observe and interact with both Syrian refugees and Jordanian policy makers.

The article pursues following structure. It first overviews the literature on refugees' labor market integration by focusing on diverse actors and competing interests. Then, it maps the perspective of Jordanian state and links it to the donor's perspective. This section focuses on the alignment of the perspectives that created to the Compact in 2016. The following section moves to provide insights about the refugees' perspective and the challenges they face in the labor market. Then, the article exemplifies the host community perspectives. The article concludes with a review of findings and policy suggestions.

\section{Refugees Labor Market Integration: Multiple Actors and Competing Interests}

Although the 1951 Convention Relating to the Status of Refugees proposes the right to work among the basic minimum standards for the treatment of refugees, host states have a power of discretion to decide refugees to work or not in private and public sector as well as the possibility of self-employment. Refugees are rarely provided general support such as using public employment services, validation of skills, educational/ vocational training, and the recognition of academic/professional qualifications that are vital for labor market integration. In the case of refugees' employment, their working rights are not fully protected by host state authorities. The main driving forces for host states' inattentive or restrictive policy choices are the fear that refugees will take the jobs available to citizens (Zetter and Ruaudel, 2016).

For the countries hosting mass refugee flows, there are additional deterrent factors, as mass arrivals are perceived as or are in actual shock to the local economy and 
resources of local communities (Betts and Milner, 2006). The negative impact of mass arrivals may tend to show up in macroeconomic indicators - such as unemployment and inflation - and swell the ranks of those living below the poverty line. This often comes on top of sharp declines in regional trade and tourism that flow from the very conflicts that have driven refugees to flee across borders in the first place (Harper et al., 2016:12). Also, as most of the urban refugees settle in neighborhoods along with poor host communities, it is believed that this may worsen public services, rise competition for limited low-income job opportunities, and lower standards of living.

Unlike the general perceptions about negative impact, evidences from mass refugee situations show that both the perceived and real impact of refugees on the living conditions of locals are mixed (Codjoe et al. 2013; Alix-Garcia and Saah, 2009). In the case of Liberian refugees in Ghana, Codjoe et al. (2013) find that refugees increased the costs of goods and services, brought the pressure on facilities, and deteriorated the environmental resources on the one hand, emerged as new market and trade partners on the other hand. The case on Rwanda and Burundi refugee inflows in Tanzania shows that refugee camps have positive wealth effects on nearby rural households, while they negatively affect the wealth of on households in urban areas (Alix-Garcia and Saah, 2009). Another study on Tanzania indicated that mass refugee presence affects refugee hosting population's welfare, differently depending on the hosting households' main initial occupation (Maystadt and Verwimp 2014).

Although there are mixed influences of mass refugee arrivals on economy, host governments consider necessity and urgency to take policy interventions for mitigating resentment of host communities about perceived or possible competition. Encampment and other forms of restrictions over the mobility are used to keep refugees distant from the labor market (Turner, 2015). Dissemination of discourse on the securitization or criminalization of refugees is also served as a restrictive measure. In the cases of more flexible host country policies about refugee employment, lack of attention to the inadequate human capital of refugees which are often attributed to refugees' language barriers, having less working experience, poorer mental and physical health, and residing in more disadvantaged neighborhoods appear as additional factor sets impeding employment (Connor, 2010:377). Under these conditions, refugees living in urban areas end up with facing protection and livelihood problems, while aid agencies and host governments take supportive or hindering roles in refugees' effort to overcome challenges (Jacobsen, 2006).

On the other hand, an observable pattern for many hosting countries is that urban refugees' access to an informal and/or private sector is more immediate and easier than their access to a formal and/or public sector as well as easier that working of camp refugees. Refugees usually find jobs more easily in labor-intensive sectors like construction and agriculture rather than other sectors where their qualifications and skills mostly fit. The business networks or previous labor migration ties between origin and host country may play a facilitative role in refugee's placing in a job. But in general, informal job opportunities carry out risks about workers' rights and poor conditions. Refugees are constrained into exploitative employment conditions, low salaries, long working hours, and a lack of legal ways to seek justice.

However, integration into the labor market is the first priority for many refugees, as it may eliminate their severe economic hardship, multiple deprivation, and impoverished existence (Jacobsen 2001, 2002). Employment appears as "the dominant 
pathway for refugees' economic security and regaining their lost dignity, humanity and respect" (Losoncz, 2017: 47). As Landau and Duponchel write, employment in the case of urban settlements is the core of "silent integration" (2011: 1). Nonetheless, this integration relates to how it is perceived by receiving communities. The most common concern of receiving communities is the possible rise in the competition at labor market due to the increase in population. It is possible that refugees compete with vulnerable urban residents - often internal/domestic voluntary migrants and poor marginalized residents on the one hand. They almost everywhere "engage in significant levels of market activity" by increasing consumption and production as well as lead to an intense flow of monetary and human capital on the other hand (Betts and Collier, 2017: 2).

Beside stances of host state and host community, perspectives of international humanitarian actors and donors about integration matter, particularly in the first destination countries in the Global South as international actors, cover some needs of refugees. Although humanitarian aid helps to meet the immediate needs of refugees in the early years of the arrivals, it remains inadequate for the realization broader aim of "protection in regions of origin" (Crisp 2003; Hanafi et al., 2014). Development assistance is considered crucial for strengthening the protection capacity of refugee hosting countries, promoting self-reliance and local integration of refugees (Betts and Milner, 2006:3). This approach, supported by the UN, World Bank, EU, and others, strategically targets middle-income countries such as Lebanon and Jordan (Crisp 2017). The idea of self-reliance serves the financial aims of the donor community often located in the Global North, which is also the major funder for UNHCR, as it is a "cost-effective exit strategies from long-term refugee populations" (Easton-Calabria and Omata, 2018. An ideal strategy for this is to create jobs for refugees in there (Betts and Collier, 2017:172). However, the approach based on international assistance to foster refugees' self-reliance through employment has an unsuccessful historical record as well as problematic links with neoliberalism and the notion of dependency (2018: 1458).

From the perspective of host states, international development assistance appears to be the most desired mean for improving the conditions for refugees, affected host communities, and capacity of central and local agencies. Against this backdrop, the development assistance refugee employment nexus increasingly become an item in the bargaining/negotiating process of host states with international donors. While the donors advocate for refugee employment in negotiations, many host states, particularly experienced countries like Jordan, Turkey, and Pakistan, are "far from passive recipients of either aid or refugees." (Kelberer, 2017:150). They adopt several discursive and policy strategies to attract higher levels of funding. They have the greater agency in their relations with the donors more than it is actually portrayed (Kelberer, 2017: 150). They use their refugee policies as leverage in international negotiations to lobby for getting more aid and use the threat of withdrawing protection and services or letting refugees to leave the country for further destinations when the aid is not delivered. To identify this pattern, Kelberer introduces the term of "refugee rentierism which is defined as the phenomenon of using host status and refugee policy as primary mechanisms of international rent-seeking" (Kelberer, 2017: 157). She notes that "while nearly all host states engage in some form of rent- seeking in international aid negotiations, the predominance of this type of assistance in refugee rentier states has significant policy impacts" (Kelberer, 2017: 157). The historical and prominent country example of refugee rentierism is Jordan. Adopting a new terminology, drawing from 
the case of Jordan too, Arar (2017b) called the same phenomenon "new grand compromise" that refers to process in which "major refugee host states in the Global South, especially those with large Syrian refugee populations, were able to leverage the value of their refugee hosting capacity and renegotiate policies to promote state-centric agendas" (p. 298).

\section{The Perspective of Jordanian State About Refugee Employment and Negotiating with Donors}

Jordan - with its population up to $10,053,000$ - hosts the second largest number of refugees relative to the size of its population with 89 refugees for every 1000 inhabitants, according to the UNHCR update in April 2017 (Population Estimates 2017; UNHCR $2017 b$ ). The UNHCR's population of concern is 728,955 people of whom 655,732 are Syrians (UNHCR 2017a, 1). The Government of Jordan (GoJ), which does not label Syrians as refugees, estimates that 1.4 million Syrians live in Jordan. These estimates are higher than UNHCR's figures as it counts Syrians who were living in Jordan before the crisis and unregistered Syrians who entered the country but have not sought formalization of their status with UNHCR (JRP, 2016-2018: 14). In addition to Syrian refugees, Jordan hosts Palestinian, Iraqi, Somalis, and Sudanese refugees as well as a quite large number of labor migrants from Egypt and South Asia. It should be noted that it was widely suspected that Jordanian state authorities used to exaggerate the number of refugees (both Syrians and Iraqis) within its border to solicit greater financial contributions from the external donors (Arar, 2017a; Sahin Mencutek 2018:224).

An important policy change - granting Syrian refugees right to work - occurred in 2016 as a departure point from Jordan's previous restrictive policies. GoJ's negotiations with the European Union (EU), widely known as Jordan Compact, led to granting working permits to Syrian refugees (Jordan Compact, 2016). It is observed that there is an uneasiness of Jordanian public about giving working permits to Syrian refugees, while conditions of Syrians' employment have limitedly improved.

Employment of Syrian refugees in Jordan is a complex issue economically as well as politically considering the high number of migrant workers and Jordan's policy legacy and memories about Palestinian and Iraqi refugees (Lenner 2016). The unemployment rate among Jordanians prior to the Syrian conflict was above $14 \%$ and rose to $15.8 \%$ in 2016 (Al Sharif, 2017). Particularly, both female and youth unemployment (1525 years) were considerably high, standing at around $30 \%$ for both groups (Stave and Hillesund, 2015:6). Moreover, Jordanian labor market is very fragmented. Great numbers of Jordanians work in a large public sector and the armed forces (Aita, 2008:40). Non-Jordanians, including Palestinian and Iraqi refugees as well as Asian and Egyptian migrant workers, dominate private sectors. Jordan has also a substantial informal economy which is characterized by low and declining wages, longer working hours, and poor working conditions and regulations (Kattaa, 2016:73).

Under the pressure of unemployment and informal labor market conditions, Jordanian state aimed at preventing Syrian refugees to compete with Jordanians for scarce job opportunities. However, the 2001 workforce agreement between Syria and Jordan enabled Syrians who had been in Jordan prior to 2011 immediate access to labor market (Agreement 2001). This legal window of opportunity and previous labor migrant 
networks allowed Syrian refugees arriving after 2011 immediate access to private sector and self-employment (Errighi and Griesse, 2016:12). However, this did not ensure the access of all Syrian refugees to labor market with secure conditions and their access to support about employment as well as to enjoy working rights. This turned out a high competition over employment between Jordanians and Syrian refugees and migrant workers (Grawert and Alhomeimat, 2019).

In 2016, the issue Syrian refugees' access to Jordanian labor market was internationalized at the Supporting Syria and the Region Conference (known as the London conference). In this conference, Jordan presented its very advanced plan called Jordan Compact: A New Holistic Approach between the Hashemite Kingdom of Jordan and the International Community to deal with the Syrian Refugee Crisis. The Compact concretely asked attracting increased foreign investment in Jordan, opening up the EU market with simplified rules of origin to the Jordanian exports and soft loans. These demands were legitimized as Jordan has "a significant fiscal needs of its own, exacerbated by conflict in the region, the cutting of its principal exports routes and markets and the cost of hosting refugees." (Jordan Compact, 2016). Fulfillment of Jordanian demands is expected to make positive changes in the macro-level economic conditions in the country, specifically by reducing its debt level and financing gap (EC, 2016b: 13). Also, any improvement in the economy would contribute to creating more jobs that can benefit both Jordanians and Syrians (Kattaa, 2016:74). Jordan stated that it was in need of "additional funding to provide direct support for Syrian refugees, as well as ensuring that the communities hosting them are not adversely affected.'(Jordan Compact, 2016). The Jordan Compact focused on an improvement of the resilience of refugee and host communities with a specific emphasis on livelihoods and education. Jordanian government was hopeful that hosting Syrian refugees could be turned into a chance to be able to get development aid from the EU and chance to sign the free trade agreement with the EU that is similar to the US and Jordan signed in 2000.

In the Compact, the GoJ promises to introduce the right of employment for Syrians refugees if the international community would accept the financial and trade-related demands (JRP 2017-2019, Section VI). The GoJ proposes to undertake the necessary administrative changes to allow for Syrian refugees to apply for work permits (Jordan INGO 2017). It stresses that the number of jobs for Syrian refugees would be conditional upon the level of international support (Jordan Compact 2016). As the addressee of the Compact, during the negotiations, the key international donor states such as the UK, the USA, Canada, Japan, and the European Commission alongside the World Bank and International Monetary Fund (IMF) particularly focused on granting working rights to refugees to improve their self-reliance as well as to generate positive outcomes for Jordan and its host community (Gray Meral 2019).

Their emphasis is partially genuine. Due to a large number of Syrian refugees arriving in Europe in 2015, the EU has sought solutions in the region. It urged host states like Jordan, Lebanon, and Turkey for granting more rights including working rights and citizenship to Syrians that would enable them to stay in their first host country, instead of seeking asylum in Europe. Given this win-to-win negotiations between GoJ and donors, mainly EU, the Jordan Compact was finally turned into the EU-Jordan Compact which is framed as part of the EU-Jordan Partnership Priorities 2016-2018. It replaced the EU-Jordan Action Plan of 2012. The Compact publicized by the European Commission (EC) in September 2016 (Jordan Compact, 2016:10). In 
addition to providing additional loans and humanitarian aid, the EU relaxed the rules of origin for imports for a period of 10 years for a wide range of products available to producers in Qualified-specialized Industrial Zones ${ }^{2}$ (EC, 2016a:1). This relaxation is conditional upon offering of job opportunities under the same conditions for both Jordanians and Syrian refugees (15\% of jobs in first 2 years; $25 \%$ thereafter). Once the target of 200,000 jobs for refugees is achieved at the country level, an extension of the rules of origin regime is foreseen (EC, 2016a:2).

All of these incentives and expectations convinced Jordan to allow Syrian refugees' employment into selected occupations of the labor market and to issue less costly and flexible working permits. To ensure that Syrians do not replace Jordanian workers, the GoJ allowed Syrians to participate into the labor market only in 18 qualified industrial zones, in refugee camps, certain sectors (e.g., agriculture and construction according to predetermined quotas), and for municipal public works funded by donor community grants (EC, 2016b: 13). In addition, Jordan accepted the formalization of Syrians' existing businesses and setting up new tax-generating businesses (Jordan INGO 2017). However, pertinent state departments not only lack clear application procedures and regulatory framework but also tend to put legal barriers in the registration and licensing of Syrian businesses and regularizing their working staff (Bellamy et al. 2017: 55). In April 2016, the Ministry of Labor (MoL) allowed a grace period of 3 months for Syrian refugees working without a work permit to regulate their employment status and then extended the grace period until the end of 2016. The MoL also waived fees required to obtain a permit (Kattaa 2016:75).

So, granting working rights to Syrian refugees by Jordan emerged as the trade-off between the pressure of the international community and the fulfilling of incentives requested by the GoJ. The GoJ's decision also partly reflected the needs of neoliberal economic policies for cheap labor and mounting concerns about the sustainability of providing social protection to large numbers of Syrians without getting state revenues in return through taxes and contributions to economic growth. Compact was portrayed as a promising global policy model not only for contributing to the economic development of host states but also for supporting the self-sustainability of refugees (Lenner and Turner, 2019). However, the Compact encountered many shortcomings in its implementation, undermining the fulfillment of three main strategies "the expansion, substitution, and formalization of employment" (Lenner and Turner 2019:90) due to the characteristics of the Jordanian labor market and political economy after 20 years of neoliberal transformation. The Compact made the refugees part of the political economy structure based on segmented and informalized labor market, extensive use of migrant labor, spatial segregation into economic zones, and specific labor regime exploiting labor migrants (Lenner and Turner 2019).

In a few years, it appeared that many conditions envisioned in the Compact that is linked to the refugee employment are inapplicable. From a Jordanian perspective, "it is not really an added value; it is unfair to put such conditions on us." ${ }^{3}$ Not only the employment of Syrians permanently in factories but also getting a license for exports by factories turned into

\footnotetext{
$\overline{{ }^{2} \text { International Labor Organization }}$ defines Qualified Industrial Zones as "an industrial estate that specializes in manufacturing for export. These zones are established with special incentives to support free trade and attract foreign investors. Working conditions and industrial relations in these zones often do not meet international labor standards" ILO 2017. "Media-friendly Glossary on Migration, Middle East Version,” 20 January, http://www.ilo.org/beirut/projects/fairway/WCMS_552778/lang\%2D\%2Den/index.htm\#H

${ }^{3}$ Interview of Migration Expert from Jordan - online, 28 January 2018
} 
a quite challenging procedure. ${ }^{4}$ Evidences proved that the formalizing worker has been extremely challenging in the context like Jordan as all other market forces encourage informality (Lockhart, 2019). At least four major problems are notable. First, "Syrian refugees became dependent on work permits to access legal work and this was limited to a select number of low-skilled sectors, putting highly skilled refugees in disadvantages position (Gray Meral 2019). Second, linking work permits to the employer failed to minimize the risks of exploitation of refugee workers (Gray Meral 2019). Third, the continuation of unfavorable conditions of work inside economic zones - such as harsh working conditions and low wages - nonenforcement of labor law protections, and enhanced informality raised undermined the expected benefits of the Compact on the refugees' socioeconomic conditions (Gray Meral 2019; Lenner and Turner, 2019). Fourth, the Compact's promise to attract foreign investments through trade concessions has proven hard due to the complexities in implementations. In 2018, benefiting from the deal, only three factories in Jordan were able to export to Europe, while only eight factories fulfilled all conditions. Also, work permits to Syrians remained less than the target of 200,000 (Jordan MoL, 2019). Majority of the permits are in agriculture, construction, and manufacturing sector. Moreover, an access to self-employment of Syrians has become more challenging for refugees in Jordan since the Compact (Gray Meral 2019).

Razzaz (2017) point out two additional factors behind the misalignments between the perspective of Syrian refugees and the expectations of host states and donors by the Compact. First, Syrians have families with them unlike migrant workers who came Jordan alone, thus the former neither is able to work under some of the conditions feasible for migrant workers nor their wages in some sectors such as manufacturing sufficient to cover rent and other basic needs of families. Second, migrant workers' permit is temporary basis and taken from outside of the country, fitting of this model to refugees is impossible for refugees (Razzaz 2017:13).

In the light of emerging needs and failures in meeting the Compact's preconditions, several amendments have been adopted since 2016. GoJ introduced eight grace periods for Syrian refugees work permits valid, extending until 31 December 2019 (Jordan MoL, 2018). Formal employment of Syrian refugees in Jordan extended to five sectors - including agriculture, construction, food and beverage services, manufacturing, and wholesale and retail trade (Lockhart 2019). Jordanian government asked for the revision of the EU-relaxed rules of origin for Jordanian exports (Ghazal 2018). The Jordanian Council of Ministers' new instructions on 22 November 2018, related to home-based and small businesses for Syrians, opened more working spaces for the refugees living outside the camps. They are granted rights to register and operate homebased businesses in three sectors: food processing, handicrafts, and tailoring (Jordan MoL, 2018). However, amendments remained superficial without touching the structural problems of Jordanian labor market causing the low performance (Grawert 2019).

\section{Syrian Refugees' Perspectives About the Jordanian Labor Market}

Despite previous legal regulations which were not allowing the formal work of Syrian refugees until 2016, many of them were working in the private sector. In the camps,

${ }^{4}$ Ibid 
working opportunities are more limited, except market stall enterprises, jobs in food and transportation sectors, and volunteer positions under the scheme of cash for work opportunities provided by the UN agencies and NGOs (Kattaa, 2016:74). In the case of urban refugees, they used to temporarily work in the informal sector.

The Jordanian state shows relatively flexible approach toward working of Syrians. The rule of arresting Syrians without paper and sending them back to camp is believed to be on paper, but not strictly implemented till the last years. ${ }^{5}$ However, according to the human rights organizations, since 2014 and especially in 2016 and 2017, Jordan made a reputation for deporting Syrian refugees without explanation or chance to challenge the decision (HRW 2017). So, working without permits put refugees into the vulnerable position as it contains risks of arrest, relocation, repatriation to camps, or deportation.

Due to the double informality for some Syrians - not being registered as refugees and working in informal jobs - accessing the exact statistics about how many Syrians actually work is a quite challenging task for researchers. According to Stave and Hillesund (2015), almost 51\% of Syrian men residing outside the refugee camps participate into the Jordanian labor force. Almost $90 \%$ of these employed Syrians were working in the informal economy (Stave and Hillesund, 2015:5). For the same period, the survey report of CARE noted that $78 \%$ of Syrians is reported as not working (meaning only $22 \%$ work), compared to $65 \%$ of Jordanians - up since 2016 (CARE Report, 2017:2). Only $10 \%$ of employed Syrians has work permits lasting until 2015 (Lenner, 2015:12; Errighi and Griesse, 2016: 5). There is almost no statistics available on the number of female workers, although it was known that Syrian women are working in jobs both in part-time and full time basis. ${ }^{6}$

After the Jordan Compact in 2016, both urban refugees and those refugees in the camps obtained a legal right to work. Bureaucratic procedures, such as getting permits, are presented as becoming easier. Camp refugees are allowed to work outside the camp which is conditional upon securing the legal permission of leave. Also, an issuing of work permits provided more concrete statistics about refugees' employment, at least regarding the participation into formal labor market. As a result of increasing trend started in April 2016 with the grace period, some 38,000 Syrians have obtained valid work permits by 2017 (Fact Sheet, 2017). From January 2016 to April 2019, 142,520 permits were issued. However, many of them have been either for renewal or workplace change rather than first time issuance (Jordan MoL, 2018). However, the number of applicants for getting permits remained smaller than expected because of the lack of available work opportunities, fear of losing assistance or chance of resettlement, high costs for permits, and employers' refuse of pay associated costs (Kattaa 2016:76; CARE Report, 2017:2). As a result, the number of Syrian refugees who work without permit is much higher than those having it. Also, a legal right to work does not necessarily eliminate Syrian refugees' concerns about contacting with officials. ${ }^{7}$

\footnotetext{
${ }_{5}^{5}$ Personal communication with the retired Deputy Security Manager of a refugee camp, Irbid/04 February 2018

${ }^{6}$ Personal communication with representative from London-based INGOs conducting humanitarian projects in Jordan and Lebanon, online interview/30 January 2018

${ }^{7}$ Personal communication with representative from London-based INGOs conducting humanitarian projects in Jordan and Lebanon, online interview/30 January 2018
} 
The matching of refugees' qualifications and skills with the needs of Jordanian labor market is an important dimension of employability of refugees. This dimension became more critical with the Compact which ties refugee employment with the export from 18 industrial zones. In this line, Jordan needs qualified workers for manufacturing industry which is filled by Egyptian and South Asian migrants for years. After 2016, some Syrian refugees residing in refugee camps were recruited from textile factories in the close industrial zones. ${ }^{8}$ The recruitment was facilitated by the previous targeted support of associations providing women vocational training in camps. One of these working women explained the recruitment process as such:

I took a sewing course with IRD [International Relief and Development]. After a while, I had a phone call from my friend and she asked me if I was able to work now. So, I told her that I would love to work. She told me it is a sewing job, but outside the camp. I said yes. Then, IRD office in unit 10th in the camp called me for an interview in a sewing factory outside the camp. I was the first person who was interviewed, I had a certificate from the UNWomen, from IRD, and from Abdullah Moubark's project as well. So, they signed the contract with me immediately. ${ }^{9}$

Syrian women interviewed in the camp reported that they were only able to work for such jobs in textile factories for a short duration like few months, although they obtained working contracts, working permit, and necessary forms to leave the camp officially. Then, they left the job due to the long working hours, long daily commuting to factories from the camp, child-care responsibilities (or pregnancy), and other difficulties such as not getting used to work. ${ }^{10}$ Growing economic needs of families are the main driver of women's employment although they reported that they had not been working in Syria before migrating to Jordan. In the host country context, an inadequacy of their husbands' income and the loss of social-familial support that they had enjoyed in Syria made their contribution to the family income necessary. ${ }^{11}$ An interviewed woman who worked for 3.5 months in a textile factors lists the challenges which she faced during her working experience:

First is to work with men. I was not used to this before. Second, the time that we spent to arrive work place is too long. I used to wake up around 5 a.m., then pray and leave to work at 6 a.m. We had to walk for one hour to get to the camp's door because the buses used to take workers from the door of camp. [This is recently changed]. We were starting work at 7 a.m. and we were leaving at 4 p.m. with only half an hour break. ... Half an hour was not enough. Nothing provided for a lunch and for a breakfast. Salary was just 205 J.D. $^{12}$

Another challenge for refugee workers is about the treatment of managers and negative attitudes of locals. Our Syrian interviewee noted how they are accused:

They were telling to me that 'you - Syrians - were the cause of increasing the unemployment for Jordanians'. They were telling us that 'you- as Syrians took

\footnotetext{
${ }_{8}^{8}$ Personal communication with a Syrian woman working in Jordan, 2 April 2018

${ }^{9}$ Personal communication with a Syrian woman working in Jordan, 25 April 2018

${ }^{10}$ Personal communication with two Syrian women working in Jordan, 25 April 2018

${ }^{11}$ Personal communication with a Syrian woman working in Jordan, 25 April 2018

${ }^{12}$ Personal communication with a Syrian woman working in Jordan, 25 April 2018
} 
Jordanians' job opportunities. They add that 'these jobs should have been for Jordanians, not for Syrians. ${ }^{13}$

For women, familial and social pressure coming from other Syrian refugees in the camp, particularly about child-care issues, seems as an additional impediment for longterm working. ${ }^{14}$ For urban refugees, a lack of recruitment support, the temporality of contracts and jobs, and low salaries are added into the long problem list. ${ }^{15}$

Despite all these challenges, the employment benefits working refugees by improving their "economic situation" such as paying some debts, ${ }^{16}$ ensuring their "selfreliance," making them "more self-confident," and providing socialization opportunities and venues for integration. ${ }^{17}$ A Syrian woman working for an NGO as a trainer explained the benefits by covering several dimensions:

Working, in general, is the important source to have a financial resource to live a good life, without asking for aid from other people, and without having to go to the NGOs or charities where we might be insulted. So, for us working is part of our dignity, even if it was for low salary rates. We will accept to work and we will take any job opportunity in any field, the most important thing is not to ask from others. This gives me a relief, that I still feel self-glory. ${ }^{18}$

\section{The Perspectives of Jordanian Host Society}

Refugees' labor market integration is also related to perspectives of hosting communities as these are employers, neighbors, policy designers, and implementers. In fact, there has been a common positive Jordanian perception about the Syrians' high qualifications, particularly in crafts. During our interviews, it has been often noted that Syrians are "skilled workers"; ${ }^{19}$ they should have an opportunity to access livelihood under some conditions particularly without jeopardizing the Jordanian citizens. ${ }^{20}$ A Jordanian migration expert whom we interviewed expressed similar ideas:

Syrians are seen as a chance to Jordan, it is recognized that they have many skills which do not exist among Jordanians; they like to work, they are very committed. On the other hand, Jordanians are known to be bad workers; even before the Compact, Syrians worked very well in the informal sector. ${ }^{21}$

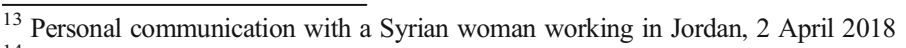

${ }^{14}$ Personal communication with two Syrian women working in Jordan, 25 April 2018

${ }^{15}$ Personal communication with a Syrian woman working in Jordan, 2 May 2018

${ }^{16}$ Personal communication with a Syrian woman working in Jordan, 2 May 2018

${ }^{17}$ Personal communication with a Syrian woman working in Jordan, 2 May 2018

${ }^{18}$ Personal communication with a Syrian woman working in Jordan, 2 May 2018

${ }^{19}$ Personal communication with a representative of Syrian transnational NGO serving in Jordan, Irbid, 24 March 2018

${ }^{20}$ Personal communication with a retired Deputy Security Manager of a refugee camp, Irbid, 04 February 2018

${ }^{21}$ Personal communication with a retired Deputy Security Manager of a refugee camp, Irbid, 04 February 2018; Personal communication with a migration expert from Jordan - online, 28 January 2018
} 
A director of a Jordanian charity organization's comments also reflected how integration and employment are connected: "Syrians are well-integrated into the Jordanian community, even more than it had been wanted. First evidence for this integration is the fact that refugees work in all the different fields such as in bakery stories, restaurants, supermarkets, industrial areas, and farms.",22

Even if Syrians are well-qualified and they are recruited by Jordanian employers, many Jordanians suspect that Syrians' employment put local workers into the disadvantaged position. One retired security officer explained his perspective by proposing his own solution:

I believe that refugee is a human being, and if he lives in urban areas, he needs to feed his children, I believe that, in fact it should be in the way that factories or restaurants should give jobs to both Syrians and Jordanians in equal numbers. But right now, in some restaurants, all employees are Syrians, there is no Jordanian worker. This is what is happening right now, there is a need to consider Jordanian workers, too. ${ }^{23}$

A dilemma is that labor market participation of refugees seems both a path for local integration and a "burden." A Syrian representative of a transnational NGO expressed this dilemma and its interaction with official discourse very well when we asked about what are the most important barriers in front of integration of Syrians in Jordan. He told that:

I believe that Syrians and Jordanians have a history of relationships and the share the same language and religion which make the integration easier, however there are some barriers. For example, Jordanians feel that Syrians are a burden especially in terms of work because unemployment rate is high in Jordan. They sometimes feel that Syrians are taking job opportunities of Jordanians. But we have to take in the consideration that Syrians were not allowed to work in Jordan for a long time. In fact, the speeches of politicians affect the integration as well, because when the government says that Syrians are burden, the people would say and feel the same. ${ }^{24}$

It is known that many Jordanians, including policy makers, complain for accommodating a new population group by recalling their past experiences claiming that these new comers create "burden on infrastructure and economy" (Lenner 2016: 10,13). The perceived competition for jobs was mentioned as a serious problem by almost all Jordanian interviewees. This perception may relate to the Jordanian public opinion survey results that list unemployment, poverty, and rising prices as the biggest problem facing Jordan as a whole (CSIR, 2017). Under these conditions, Syrian refugees became primary scapegoats for these economic problems (Huser, 2016: 82). Particularly, many Jordanians believe that the poorest segment of the Jordanian population

\footnotetext{
$\overline{22}$ Personal communication with a representative of local Jordanian Charity Association, Irbid, 23 April 2018

${ }^{23}$ Personal communication with a retired Deputy Security Manager of a refugee camp, Irbid, 04 February 2018

24 Ibid
} 
became unemployed because cheap Syrian labor force took their jobs (Stave and Hillesund, 2015: 5-6).

From the perspective of Jordanian employers, Syrians' acceptance of long-hour conditions works as an incentive for the recruitment of Syrians in the expense of Jordanian workers. One local director working for the Zarqa Municipality explained it:

Refugees accept to work for longer hours; this is for the benefit of the business people, people in companies for looking for these criteria. This is the reason for unemployment and poverty increased among Jordanians dramatically mainly in Zarqa and Amman where have the majority of people, meaning $60-70 \%$ of Jordanian population. $^{25}$

Although Jordanians feel that they are worse off or the employment opportunities tighten because of the Syrians, the findings of recent studies present a different picture. Carrion notes that Jordanian host communities benefited not only from the presence of refugees but also from the international aid that has come with them (Carrion 2015:2). Both Fallah et al. (2019) and Hartnett (2018) show that Jordanians living in areas with a high concentration of refugees have had no worse labor market outcomes than Jordanians with less exposure to the refugee influx. However, it is reported that labor market pressures and working permits to Syrians refugees increased to the vulnerability of Egyptian migrant workers (Hartnett, 2018). Chatty (2017) argues that Jordanian policy maker are aware of the fact that Syrians contribute to the Jordanian economy in a greater fashion than is written in the media and circulated in the society framing Syrians as a "burden" on Jordanian economy.

Contrasting to the quotation about competition, the analysis of Malaeb and Wahba (2018) demonstrates that refugees mainly compete with economic migrants not with Jordanian natives. It is also reported that Syrian workers have been largely replacing Egyptian and South Asian migrant workers and not Jordanians in many sectors (Mayer, 2016: 22). As a result, these immigrant workers have to work under the conditions of longer hours and lower wages due to the refugee influx (Malaeb and Wahba, 2018: 18).

While the cases of long-hour working of Syrians has been common for informal job market from the beginning, the concerns of Jordanians seem to have worsened with the legal working right granted to Syrians as it might imply the rising of salaries for Syrians. It is believed that "this makes Jordanians angrier." The competition is relatively more acute in some sectors and cities, as Fallah et al. (2019) show that Syrian refugees compete with less educated Jordanians in certain sectors such as construction.

Another dimension which is pointed about the "unfair" competition in the labor market is about refugees receiving aid and working simultaneously that is believed to put poor Jordanians into the more disadvantageous position. Defying these claims, current studies show that employment increasingly becomes the main income for many Syrian households. A 2017-10 survey on Syrians living conditions in Jordan shows that "51 per cent of all Syrian refugee households rely primarily on employment income; 26 per cent report transfer income only and 7 per cent rely mainly on transfers;

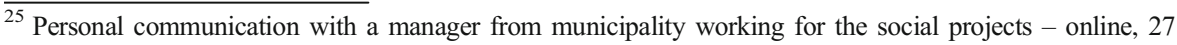
January 2018
} 
13 per cent of all households combine employment and transfer income; and 2 per cent of all households rely primarily on other income sources" (Tiltnes et al., 2019:8).

Additional contested issue that came with the Jordan Compact is the Syrian's employability in municipal public works which is funded by donor community grants. Interviewees from municipalities expressed their reluctance for hiring any Syrians at the moment in the municipality. One high-level municipality staff said that "this decision is still negotiated in the municipality, and maybe in the future it could be applied or not." ${ }^{36}$ The issue of Syrians' employability became a tension point when municipalities are funded by international NGOs for a specific project. Some INGOs demand municipalities to hire Syrians for the projects they provide funds. However, Jordanian directors in the municipality found such conditions unfair. He stated that "we were hoping to recruit more Jordanians, for sure, because we are providing Syrians with the services and work, in this case more employment opportunities should be allocated for the citizens from the hosting community.,27

\section{Conclusion}

Refugees' access to labor market is a crucial aspect of the local integration. However, receiving governments in the Global South tend to make limitations for the legal employment of refugees, although they do not necessarily put severe restrictions of the working of urban refugees in informal sectors.

This paper has examined the labor market integration of Syrian refugees in Jordan. It has focused on the issue by identifying diverging perspectives on refugees' labor market integration: legal regulations of Jordanian state, the intervention of donors, the actual participation of Syrians in formal and informal Jordanian labor market, and the concerns and reactions of Jordanians. To consider the relevance of each perspective, Jordan serves as representative case at least for three reasons: It is historically and now one of the main refugee-hosting country. Refugee employment is used to be a sensitive issue for the country, but many refugees access to private informal sector despite harsh conditions. It is one of the refugee rentier states as it uses its host status and refugee policy as primary mechanisms of international rent-seeking, particularly to draw financial resources. The most recent example of international negotiations over refugees is the Jordan Compact. While Jordanian state and donors considered the Compact as an ideal solution and fruitful agreement, host communities perceive it as a regulation that does not really benefit Jordanian citizens because of creating inapplicable conditions. Syrians approached it as an unbeneficial agreement as it does not cover all needs for access to labor market and working rights.

Some lessons from the Jordan case are the following; First, donor interventions, such as the Compact, may not generate the desired impacts if they do not take the labor market characteristics into account. Jordan exemplified the challenge of formalizing refugees' employment in contexts in which all other market forces appear to encourage informality (Lockhart, 2019). Second, as discussed in the growing literature of politics

\footnotetext{
${ }^{26}$ Personal communication with engineer and a project manager in Irbid municipality, Irbid, Jordan, 04 February 2018

${ }^{27}$ Ibid
} 
of refugee governance, international responses to Syrian refugee migration that are mainly based on protection in region of origin increased the leverage of refugee hosting countries of Global South. For example, Jordan and Turkey assertively have used the refugee hosting as an opportunity to negotiate with international institutions and donor countries, offering to alleviate the "crisis" or providing temporal protection in exchange for political and/or monetary payoffs. Lebanon has pursued a similar pattern but fell behind the other two countries, making fewer demands from donors and securing less financial aid. Granting working permits to limited number of Syrian refugees or introducing some local integration mechanisms, particularly refugee's access to education and health, have been on the negotiation items, requested by donor states. Third, it seems that all stakeholders - host state, refugees, local community, and international donors - should be given voice to be able to find the more beneficial, less costly programming for sustainable and dignified economic integration of refugees. Rightbased approach and well-being approach may be more reflected on policies addressing refugees' employment rather than current neoliberal policy approach of host states and protection in the origin region approach embraced by donors and international refugee regime.

Acknowledgements Open Access funding provided by Projekt DEAL.

Open Access This article is licensed under a Creative Commons Attribution 4.0 International License, which permits use, sharing, adaptation, distribution and reproduction in any medium or format, as long as you give appropriate credit to the original author(s) and the source, provide a link to the Creative Commons licence, and indicate if changes were made. The images or other third party material in this article are included in the article's Creative Commons licence, unless indicated otherwise in a credit line to the material. If material is not included in the article's Creative Commons licence and your intended use is not permitted by statutory regulation or exceeds the permitted use, you will need to obtain permission directly from the copyright holder. To view a copy of this licence, visit http://creativecommons.org/licenses/by/4.0/.

\section{References}

Agreement. (2001). Agreement on Workforce Cooperation between the Government of the Hashemite Kingdom of Jordan and the Government of the Syrian Arab Republic. http:/www.jedco.gov.jo/.

Aita, S. (2008). Employment and Labor Law In The Arab Mediterranean Countries and The Euromediterranean Partnership, Fundación Paz y Solidaridad Serafín Aliaga de Comisiones Obreras. Madrid.

Al Sharif, O. (2017). Have GCC countries turned their backs on Jordan?. Al-Monitor, January 31, 2017.Retrieved from http://www.al-monitor.com/pulse/originals/2017/01/jordan-economic-crisis-aiddonors-gcc- regional-turmoil.Html\#ixzz4v6dW5Oxm.

Ali, Y., Sabir, M., \& Muhammad, N. (2018). Refugees and host country nexus: A case study of Pakistan. Journal of International Migration and Integration, 20, 137-153. https://doi.org/10.1007/s12134-0180601-1.

Alix-Garcia, J., \& Saah, D. (2009). The effect of refugee inflows on host communities: Evidence from Tanzania. The World Bank Economic Review, 24(1), 148-170.

Arar, R. (2017a). Leveraging sovereignty: The case of Jordan and the international refugee regime. Refugees and Migration Movements in the Middle East, 12.

Arar, R. (2017b). The new grand compromise: How Syrian refugees changed the stakes in the global refugee assistance regime. Middle East Law and Governance, 9(3), 298-312.

Beaman, L. A. (2011). Social networks and the dynamics of labour market outcomes: Evidence from refugees resettled in the US. The Review of Economic Studies, 79(1), 128-161. 
Bellamy, C., Haysom, S., Wake, C., \& Barbelet, V. (2017). The lives and livelihoods of Syrian Refugees: a study of refugee perspectives and their institutional environment in Turkey and Jordan. Humanitarian Policy Group, Overseas Development Institute, London. https:/www.odi.org/sites/odi.org. uk/files/resource-documents/11343.pdf.

Betts, A., \& Collier, P. (2017). Refuge. Transforming a broken refugee system. London: Allen Lane.

Betts, A. and Milner, J. (2006). The externalisation of EU asylum policy: The position of African states. Working paper no. 36, University of Oxford, 2006 WP-06-36.

Bevelander, P., \& Pendakur, R. (2014). The labour market integration of refugee and family Reunion immigrants: A comparison of outcomes in Canada and Sweden. Journal of Ethnic and Migration Studies, 40(5), 689-709.

Bloch, A. (2008). Refugees in the UK labour market: The conflict between economic integration and policyled labour market restriction. Journal of Social Policy, 37(1), 21-36.

Care Report. (2017). Factsheet care Jordan - Syrian refugee, other minority refugee, and Jordanian host households survey results in brief. June. https:/www.care.at/wp-content/uploads/2017/06/2017-CAREJordan-Syrian-refugees-Fact-Sheet-final-web-15062017.pdf.

Carrion, D. (2015). Syrian refugees in Jordan: Confronting difficult truths. London: Chatham House, The Royal Institute of International Affairs.

Chatty, D. (2017). The Syrian humanitarian disaster: Understanding perceptions and aspirations in Jordan, Lebanon and Turkey. Global Policy, 8, 25-32.

Codjoe, S. N. A., Quartey, P., Tagoe, C. A., \& Reed, H. E. (2013). Perceptions of the impact of refugees on host communities: the case of Liberian refugees in Ghana. Journal of International Migration and Integration, 14(3), 439-456. https://doi.org/10.1007/s12134-012-0249-1.

Colic-Peisker, V., \& Tilbury, F. (2007). Integration into the Australian labour market: The experience of three "visibly different" groups of recently arrived refugees 1. International Migration, 45(1), 59-85.

Connor, P. (2010). Explaining the refugee gap: Economic outcomes of refugees versus other immigrants. Journal of Refugee Studies, 23(3), 377-397.

Crisp, J. (2003) Refugee protection in regions of origin: Potential and challenges. https://www. migrationpolicy.org/article/refugee-protection-regions-origin-potential-and-challenges

Crisp, J. (2017). New York declaration on refugees: A one-year report card, 19 September. https://www.rsc.ox. ac.uk/news/new-york-declaration-on-refugees-a-one-year-report-card-by-jeff-crisp

CSIR (2017). Survey of Jordanian Public Opinion, National Poll, Number 15, May 22-25. Available at: https://www.iri.org/sites/default/files/2017-7-12_jordan_poll_slides.pdf. Accessed 9 Aug 2018

Easton-Calabria, E., \& Omata, N. (2018). Panacea for the refugee crisis? Rethinking the promotion of 'selfreliance' for refugees. Third World Quarterly, 39(8), 1458-1474.

EC. (2016a). EU - Jordan Partnership the Compact. European Commission, Retrieved from https://ec.europa. eu/neighbourhood-enlargement/sites/near/files/jordan-compact.pdf.

EC. (2016b) European Commission, Brussels, September 20, 2016. JOIN (2016) 41 final. Interinstitutional File: 2016/0289 (NLE) 12384/16, ADD 1 LIMITE MAMA 179 MED 38 CFSP/PESC 720 RHJ 21.

Errighi, L., \& Griesse, J. (2016). The Syrian refugee crisis: Labour market implications in Jordan and Lebanon, European Economy Discussion Papers 029. In European Commission Directorate-General for Economic and Financial Affairs. Luxembourg: Publications Office of the European Union.

European Parliament (2016). Labour market integration of refugees: Strategies and good practices. EMPL Committee: Directorate General of Internal Policies. http://www.europarl.europa. eu/RegData/etudes/STUD/2016/578956/IPOL_STU(2016)578956_EN.pdf

FactSheet (2017. Jordan Fact Sheet. February. http://data.unhcr.org/syrianrefugees/country.php?id=107.

Fallah, B., Krafft, C., \& Wahba, J. (2019). The impact of refugees on employment and wages in Jordan. Journal of Development Economics, 139, 203-216.

Ghazal, M. (2018). Jordan calls for revision of EU relaxed rules of origin agreement. Jordan times, march 13. Retrieved from http://jordantimes. Com/news/local/Jordan-calls-revision-eu-relaxed-rules-originagreement.

Grawert, E. (2019). The EU-Jordan compact a model for burden-sharing in refugee crises?, policy brief, march, Bonn International Center for Conversion.

Grawert, E., and Alhomeimat, R. (2019). Between aid dependence, neighbourhood solidarity and the EUJordan Compact. Livelihood analysis of Syrian refugees in greater Amman. BICC working paper, 4.

Gray Meral, A. (2019). Assessing the Jordan Compact One Year On: An opportunity or a barrier to better achieving refugees' right to work. Journal of Refugee Studies, fez074. https://doi.org/10.1093/jrs/fez074.

Hanafi, S., Hilal, L., \& Takkenberg, A. (Eds.). (2014). UNRWA and Palestinian refugees: From relief and works to human development. Abingdon: Routledge. 
Harper, E., Sean, T., and Abdel Aziz, M. (2016). Forging new strategies in protracted crises: Syrian refugees and the host state economy: Syrian refugees and host state economy. WANA Institute.

Hartnett, A. S. (2018). The effect of refugee integration on migrant labor in Jordan. Review of Middle East Studies, 52(2), 263-282.

HRW (2017). "I have no idea why they sent us Back" Jordanian deportations and expulsions of Syrian refugees. Human Rights Watch, October. https://www.hrw.org/sites/default/files/report_pdf/jordan1017_ web.pdf

Huser, H. (2016). Syrian refugee crisis and its impact on Jordan. In M. Beck, D. Jung, \& P. Seeberg (Eds.), The Levant in Turmoil: Syria, Palestine, and the Transformation of Middle Eastern Politics (pp. 79-101). UK: Springer.

Jacobsen, K. (2006). Refugees and asylum seekers in urban areas: A livelihoods perspective. Journal of Refugee Studies, 19(3), 273-286.

Jacobsen, K. (2001). The forgotten solution: Local integration for refugees in developing countries. New issues in refugee research, working paper no. 45. United Nations high Commission for Refugees.

Jacobsen, K. (2002). Livelihoods in conflict: The pursuit of livelihoods by refugees and the impact on the human security of host communities. International Migration, 40(5), 95-123.

Jordan Compact. (2016). The Jordan Compact: A new holistic approach between the Hashemite Kingdom of Jordan and the international community to deal with the Syrian refugee crisis. Press release, 7 February.

Jordan INGO. (2017). Walk the talk. October 11, 2017. Jordan INGO Forum.

Jordan MoL (2018). Syrian Refugee Unit Work Permit Progress Report December 2018, Report complied by Syrian Refugee Unit at the Ministry of Labour. https://data2.unhcr.org/en/documents/download/67760

Jordan MoL (2019). Syrian Refugee Unit Work Permit Progress Report April 30, 2019, Report complied by Syrian Refugee Unit at the Ministry of Labour.

JRP 2016-2018. Jordan response plan for the Syria crisis 2016-2018. Report published by the Jordan Response Platform for Syrian Crisis and the United Nations https://static1.squarespace.com/static/522 c2552e4b0d3c39ccd1e00/t/56b7235ab6aa60861ce57a77/1454842757514/4-Jordan+Plan_Annex+\%28 Feb+4\%29.pdf.

JRP 2017-2019. Jordan Response Plan for the Syrian Crisis, 2017-2019. Ministry of Development and International Cooperation. https://static1.squarespace.com/static/522c2552e4b0d3c39ccd1e00/t/5956897 e78d1714f5b61f5c2/1498843547605/JRP+2017-2019+-+Full+-+\%28June+30\%29.pdf.

Kattaa, M. (2016). Syrian refugees' status in the Jordanian labor market. Turkish Policy Quarterly, 15(3December), 71-78.

Kelberer, V. (2017). Negotiating crisis: International aid and refugee policy in Jordan. Middle East Policy, 24(4), 148-165.

Landau, L., \& Duponchel, M. (2011). Laws, policies, or social position? Capabilities and the determinants of effective protection in four African cities. Journal of Refugee Studies, 24(1), 1-22.

Lenner, K. (2015). Alternative voices on the Syrian refugee crisis in Jordan: An interview collection. RLS Regional Office Palestine.

Lenner, K. (2016). Blasts from the past: Policy legacies and policy memories in the making of the Jordanian response to the Syrian refugee crisis. EUI working papers, MWP red number series, 32 .

Lenner, K., \& Turner, L. (2019). Making refugees work? The politics of integrating Syrian refugees into the labor market in Jordan. Middle East Critique, 28(1), 65-95. https://doi.org/10.1080/19436149.2018.1462601.

Lockhart, D. (2019). Executive summary: The Syrian refugee crisis in Jordan and its impact on the Jordanian EconomyWANA institute. Jordan: Royal Scientific Society in Amman.

Losoncz, I. (2017). Goals without means: A Mertonian critique of Australia's resettlement policy for south Sudanese refugees. Journal of Refugee Studies, 30(1), 47-70.

Malaeb, B., \& Wahba, J. (2018). Impact of refugees on immigrants' labor market outcomes. In Economic Research Forum Working Paper Series No (Vol. 1194).

Mayer, R. (2016). The right to no longer be a Refugee: The Legal Empowerment of Syrian Refugees in Jordan, Columbia University Academic Commons. https://doi.org/10.7916/D8VT1SM1.

Maystadt, J., \& Verwimp, P. (2014). Winners and losers among a refugee-hosting population. Economic Development and Cultural Change, 62(4-July), 769-809.

Population Estimates (2017). Population - Estimated population of 2017 and some of selected data. Department of Statistics Jordan. https://web.archive.org/web/20180808095228/http://dosweb.dos.gov. jo/population/population-2. Accessed 9 Aug 2018

Potocky, M. (1997). Predictors of refugee economic status: A replication. Journal of Social Service Research, 23(1), 41-70. 
Razzaz, S. (2017). A challenging market becomes more challenging: Jordanian workers, migrant workers and refugees in the Jordanian labour market. Report, Available on-line at http://www.ilo.org/wcmsp5 /groups/public/—arabstates/_ro-beirut/documents/publication/wcms_556931.pdf.

Sahin Mencutek, R. (2018). Refugee Governance, State and Politics in the Middle East. London: Routledge.

Schultz, C. M. (1994). Promoting economic self-reliance: A case study of afghan refugee women in Pakistan. Journal of International Affairs, 557-578.

Stave, S. E. and Hillesund, S. (2015). Impact of the influx of Syrian refugees on the Jordanian labor market: Findings from the governorates of Amman, Irbid and Mafraq. ILO and FAFO. https://www.ilo.org/wcmsp5 /groups/public/\%2D\%2D-arabstates/\%2D\%2D-ro-beirut/documents/publication/wcms 364162.pdf.

Tiltnes, A. A., H. Zhang and J. Pedersen (2019). The Living Conditions of Syrian Refugees in Jordan." FAFO Report.

Tumen, S. (2016). The economic impact of Syrian refugees on host countries: Quasi-experimental evidence from Turkey. American Economic Review, 106(5), 456-460.

Turner, L. (2015). Explaining the (non-) encampment of Syrian refugees: Security, class and the labour market in Lebanon and Jordan. Mediterranean politics, 20(3), 386-404.

UNHCR (2018). Figures at a glance, http://www.unhcr.org/figures-at-a-glance.html. Updated 29 September 2018.

UNHCR Operational Data Portal (n.d.). Syria Regional Refugee Response, Jordan [Last updated 29 July 2018]. Retrieved from https://data2.unhcr.org/en/situations/syria/location/36.

UNHCR (2017a).Jordan-Factsheet-February2017. http://data.unhcr.org/syrianrefugees/download. php?id=12908.

UNHCR (2017b). UNHCR Operational Update-Jordan April 2017. http://reporting.unher. org/sites/default/files/UNHCR\%20Jordan\%20Operational\%20Update\%20-\%20April\%202017.pdf.

Waxman, P. (2001). The economic adjustment of recently arrived Bosnian, afghan and Iraqi refugees in Sydney, Australia. International Migration Review, 35(2), 472-505.

Zetter, R. and H. Ruaudel (2016). Refugees' right to work and access to labor markets - An assessment. Part I: Synthesis (preliminary). KNOMAD Working Paper and Study Series, Washington: World Bank.

Publisher's Note Springer Nature remains neutral with regard to jurisdictional claims in published maps and institutional affiliations.

\section{Affiliations}

\section{Zeynep Sahin Mencutek ${ }^{1,2} \cdot$ Ayat J. Nashwan ${ }^{3}$}

$1 \quad$ Swedish Research Institute, Istanbul, Turkey

2 Kate Hamburger Kolleg, Centre for Global Cooperation Research, University of Duisburg-Essen, Duisburg, Germany

3 Department of Sociology and Social Work, Yarmouk University, Irbid, Jordan 